\title{
Different responses of primary producers to mild winter in macrophyte- and phytoplankton-dominated lakes
}

\author{
Tomasz Lenard ${ }^{1, *}$, Wojciech Ejankowski ${ }^{2}$ and Małgorzata Poniewozik ${ }^{3}$ \\ 1 The John Paul II Catholic University of Lublin, Faculty of Biotechnology and Environmental Sciences, Department of Animal \\ Physiology and Toxicology, Konstantynów 1i, 20-708 Lublin, Poland \\ ${ }^{2}$ Laboratory of Research and Nature Protection, 23-110 Krzczonów, Krzczonów Trzeci 54, Poland \\ 3 The John Paul II Catholic University of Lublin, Faculty of Biotechnology and Environmental Sciences, Department of Plant Physiology \\ and Biotechnology, Konstantynów 1i, 20-708 Lublin, Poland
}

Received: 4 July 2019 / Accepted: 18 September 2019

\begin{abstract}
Early ice-out on lakes or the absence of ice cover can lead to intense water mixing, high turbidity, and changes in nutrient balance and light conditions in the water, which in turn affect the phytoplankton community and submerged aquatic vegetation (SAV) in the aquatic environment. This study aimed to evaluate whether the effects of a mild winter on these primary producers are differentiated in two types of eutrophic lakes: phytoplankton-dominated (PDL), with a low proportion of SAV, and macrophytedominated (MDL), with extensive benthic vegetation. The physical and chemical parameters of the water, concentration of chlorophyll $a$, and the biomass of phytoplankton and SAV were investigated in four small eutrophic lakes (Eastern Poland) during the growing season after cold winters (CW) and mild winters (MW). In both types of lakes, the concentrations of soluble and total nitrogen were higher and the values of soluble and total phosphorus were lower after the MW than after the CW. The concentration of chlorophyll $a$ and the phytoplankton biomass were always higher in the PDL than in the MDL, but the increase in both parameters in the vegetation season after the MW was statistically important only in the PDL. A poor underwater light climate was stressful for the SAV in the PDL, but not in the MDL. The MW had negative effects on phytoplankton diversity and the loss of light-demanding macrophytes. However, the biomass of primary producers in the MDL seems to be more resistant to climate warming, in comparison to the PDL.
\end{abstract}

Keywords: Mild and cold winter / submerged aquatic vegetation / phytoplankton community / biogenic compound / eutrophic lake

\begin{abstract}
Résumé - Différentes réactions des producteurs primaires aux hivers doux dans les lacs à macrophytes ou phytoplancton dominants. Une fonte de glace précoce ou l'absence de couverture de glace sur les lacs peut entraîner un mélange intense de l'eau, une turbidité élevée et des changements dans l'équilibre nutritif et les conditions de luminosité de l'eau, ce qui à son tour affecte la communauté phytoplanctonique et la végétation aquatique submergée (SAV) dans le milieu aquatique. Cette étude visait à évaluer si les effets d'un hiver doux sur ces producteurs primaires sont différenciés dans deux types de lacs eutrophes : les lacs à dominance phytoplanctonique (PDL), avec une faible proportion de SAV, et les lacs à dominance macrophytique (MDL), à végétation benthique abondante. Les paramètres physiques et chimiques de l'eau, la concentration en chlorophylle a et la biomasse du phytoplancton et du SAV ont été étudiés dans quatre petits lacs eutrophes (Pologne orientale) pendant la saison de croissance après des hivers froids (CW) et doux (MW). Dans les deux types de lacs, les concentrations d'azote dissous et d'azote total étaient plus élevées et les valeurs de phosphore dissous et total étaient plus faibles après le MW qu'après le CW. La concentration de chlorophylle a et la biomasse phytoplanctonique ont toujours été plus élevées dans les PDL que dans les MDL, mais l'augmentation des deux paramètres dans la saison de végétation après le MW n'était statistiquement importante que dans les PDL. Une mauvaise luminosité subaquatique a été stressante pour le SAV dans le PDL, mais pas dans le MDL. Le MW a eu des effets négatifs sur la
\end{abstract}

\footnotetext{
*Corresponding author: tomasz. lenard@kul.pl
} 
diversité du phytoplancton et la perte de macrophytes exigeants en lumière. Toutefois, la biomasse des producteurs primaires dans les MDL semble plus résistante au réchauffement climatique que celle dans les PDL.

Mots clés : Hiver doux ou froid / végétation aquatique submergée / communauté phytoplanctonique / composé biogène / lac eutrophe

\section{Introduction}

Mean air temperature increases in the Northern Hemisphere during the last few decades have had a strong impact on the functioning of lake ecosystems (Magnuson et al., 2000; Peng et al., 2013). Climate changes have resulted in rising water temperature, shortening of periods with ice cover, and reduction in the ice thickness on lakes during winter (Todd and Mackay, 2003; Jones et al., 2010; Samuelsson, 2010). The effects of increasing temperatures on ice cover phenology is stronger in lower latitudes than in northern regions (Weyhenmeyer et al., 2004, 2005; Marszelewski and Skowron, 2006). Hence, climatic variability can promote alterations in aquatic ecosystems and cause disturbances in water quality, especially in Central Europe with its temperate climate (Dokulil et al., 2010; Lenard and Ejankowski, 2017).

The winter ice cover breakup in Poland is typically observed in mid-March. However, the timing of the ice thaw varies widely between years, usually from February to April, and is generally correlated with mean air temperatures during winter and spring (Marszelewski and Skowron, 2006). Mild winters, characterised by a short period of ice cover and early ice-out, are becoming increasingly prevalent in Polish Lowland lakes. The positive trend of mean air temperature causes longer periods of ice-free conditions and much earlier dates of the last ice break-up, which has been observed to be linked with the increase of mean air temperature in February and March over the past few decades (Degirmendžić et al., 2004; Marszelewski and Skowron, 2006; Kaszewski et al., 2009). Further shortening of the ice duration on lakes coupled with increases in lake surface temperature are projected in future scenarios for lakes of Central Europe (Dokulil et al., 2010; Samuelsson, 2010).

Short ice cover duration on lakes can lead to intensive and long-lasting water mixing (Lenard and Wojciechowska, 2013), increases in nutrient concentrations, higher biomass of phytoplankton and lower biomass of zooplankton, and much higher water turbidity (Weyhenmeyer et al., 2008; Laugaste et al., 2010). Hence, mild winters can negatively affect the underwater light climate, which modifies conditions for the development of submerged aquatic vegetation in lakes (Ejankowski and Lenard, 2015). Nevertheless, in Charadominated lakes, the extensive overwintering charophytes can hamper the development of phytoplankton species by modifying their responses to nutrient concentrations, thus weakening the unfavourable effects of a mild winter on water quality (Pełechata et al., 2015).

The presence of different winter periods, with or without ice cover, allows us to compare the changes in ecological conditions in lakes, including fluctuations in physical, chemical and biological parameters in water. Differences in the biomass of the phytoplankton community and submerged aquatic vegetation can sometimes give divergent responses, especially according to the concept of alternative stable states that defines two categories of eutrophic lakes: clear water lakes dominated by submerged macrophytes and turbid waters with poor light conditions dominated by phytoplankton (Scheffer et al., 1993; Scheffer and Van Nes, 2007).

This study aimed to evaluate whether the effect of mild winters on primary producers is differentiated in two types of eutrophic lakes, phytoplankton-dominated and macrophyte-dominated. We predicted relatively high and low resistance of submerged aquatic vegetation to climatic variability in macrophyte- and phytoplankton-dominated lakes, respectively.

\section{Materials and methods}

The study was carried out in four lakes lying in close proximity to one another, located in the Leczna-Włodawa Plain in eastern Poland, which is a part of the large crossborder Polesie region (Kondracki, 2002). The lakes are small (8.1-26.7 ha), eutrophic, and have similar morphometric characteristics (Tab. 1). The catchment basin of the lakes Głębokie and Maśluchowskie was strictly dominated by arable lands (62.6-73.5\%), and meadows (4.7-8.9\%); the proportion of arable lands in the catchment basin of Lake Gumienek is smaller (30\%), but the proportion of the lake in the catchment area is around $40 \%$. Lake Czarne is surrounded by earth dyke and has a strongly limited catchment area (Furtak et al., 1998; Ejankowski and Lenard, 2014).

Data on air temperature and total precipitation for a meteorological station in the town of Włodawa, located in the Polesie region, were taken from an online service (http://www. tutiempo.net). Using temperature records, we calculated the ice break-up date $\left(L_{\mathrm{bd}}\right)$ and mean temperature in months or seasonal periods during the year. We also calculated the total precipitation in subsequent hydrological years, in which the macrophyte and phytoplankton samples were taken. The hydrological year in Poland begins on 1 November and carries on until 31 October.

Based on the last ice break-up date $\left(L_{\mathrm{bd}}\right)$, the winter periods in 2010-2014 were divided into cold winters (CW) and mild winters (MW). Cold winters (CW) were when the last ice break-up date $\left(L_{\mathrm{bd}}\right)$ occurred later than the average date of iceout in Poland (mid-March), whereas mild winters (MW) were when the $L_{\mathrm{bd}}$ occurred before this period.

The physical and chemical parameters of the water, concentration of chlorophyll $a$, phytoplankton community, and the structure of the macrophyte community were studied in the vegetation season after the winter periods, for both $\mathrm{CW}$ and MW. The samples for analysis of the physical and chemical 
Table 1. Morphometric characteristics of the studied lakes: macrophyte-dominated (MDL, in bold) and phytoplankton-dominated (PDL), according to Wilgat et al. (1991).

\begin{tabular}{|c|c|c|c|c|c|c|c|c|}
\hline \multirow[t]{2}{*}{ Lake } & \multirow[t]{2}{*}{ Co-ordinates } & \multirow{2}{*}{$\begin{array}{c}\text { Area } \\
{[\text { ha] }}\end{array}$} & \multirow{2}{*}{$\begin{array}{l}\text { Length } \\
{[\mathrm{m}]}\end{array}$} & \multirow{2}{*}{$\begin{array}{c}\text { Mean } \\
\text { width }[\mathrm{m}]\end{array}$} & \multicolumn{2}{|c|}{ Depth [m] } & \multirow{2}{*}{$\begin{array}{l}\text { Volume } \\
{\left[10^{3} \mathrm{~m}^{3}\right]}\end{array}$} & \multirow{2}{*}{$\begin{array}{l}\text { Expected depth of epilimnion } \\
\qquad-E_{m}[\mathrm{~m}]\end{array}$} \\
\hline & & & & & $\max$ & mean & & \\
\hline Czarne & 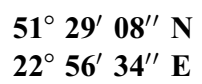 & 24.8 & 596 & 416 & 10.3 & 3.7 & 915 & 3.27 \\
\hline Głębokie & $\begin{array}{l}51^{\circ} 28^{\prime} 34^{\prime \prime} \mathrm{N} \\
22^{\circ} 55^{\prime} 23^{\prime} \mathrm{E}\end{array}$ & 20.5 & 585 & 350 & 7.1 & 3.4 & 689 & 3.16 \\
\hline Gumienek & $\begin{array}{llll}51^{\circ} 30^{\prime} & 14^{\prime \prime} \mathrm{N} \\
22^{\circ} & 56^{\prime} & 20^{\prime \prime} & \mathrm{E}\end{array}$ & 8.1 & 376 & 215 & 7.8 & 3.8 & 307 & 2.52 \\
\hline Maśluchowskie & $\begin{array}{lll}51^{\circ} 28^{\prime} & 03^{\prime \prime} \mathrm{N} \\
22^{\circ} & 56^{\prime} & 43^{\prime \prime} \mathrm{E}\end{array}$ & 26.7 & 861 & 310 & 9.4 & 4.6 & 1231 & 3.48 \\
\hline
\end{tabular}

parameters and the phytoplankton community were taken every two weeks from May to the end of August, eight samples per year in each lake. In total, 160 water samples were collected during the course of the study.

The mixed water samples were collected with a Ruttner water sampler $(2.0 \mathrm{~L}$ capacity) from the sublittoral zone of the lakes from the following depths: $0.5,1.5$, and $3 \mathrm{~m}$. The concentration of chlorophyll $a$ (Nush 1980), total phosphorus (TP), total nitrogen $(\mathrm{TN})$, and inorganic phosphorus $\left(\mathrm{P}-\mathrm{PO}_{4}\right)$ and nitrogen $\left(\mathrm{DIN}=\mathrm{N}-\mathrm{NO}_{x}+\mathrm{N}-\mathrm{NH}_{4}\right.$, Hermanowicz et al., 1999) were determined in the laboratory using spectrophotometric methods. Other physical and chemical parameters e.g. transparency by Secchi disk visibility (SD) and water reaction $(\mathrm{pH})$, were measured in situ. Photosynthetic active radiation $\left(\mathrm{PAR}, I_{z}\right.$ ) was measured by a Li-Cor 192 SA underwater quantum flat meter. Based on the measurements of underwater light in adjacent depth intervals ( $z$ and $z+0.5 \mathrm{~m})$, the attenuation coefficient $\left(K_{d}\right)$ was calculated according to Kirk (1994) as:

$$
K_{d}=\left[\ln \left(I_{z}\right)-\ln \left(I_{z+0.5 \mathrm{~m}}\right)\right] 0.5 \mathrm{~m}^{-1},
$$

where $I_{z}$ is the PAR value at depth $z$.

To determine the role of wind action in shaping of mixing regime in lakes during vegetation season we calculated the expected depth of epilimnion $\left(E_{m}\right)$ according to Patalas (1984) formula as:

$$
E_{m}=4.4 * \mathrm{D}^{0.5}
$$

where $D=\left(l_{\text {eff }}+w_{\text {eff }}\right) / 2 ; l_{\text {eff }}-$ maximum effective length of lake $[\mathrm{km}]$, and $w_{\text {eff }}-$ maximum effective width of lake $[\mathrm{km}]$.

The samples for phytoplankton analysis were fixed with Lugol's iodine solution and a formalin glycerine mixture. The abundance of phytoplankton was determined according to standard methods (Utermöhl, 1958) and the algal biovolume was calculated using a formula described by Hillebrand et al. (1999). The water samples were transferred to a settling chamber with a 5-50 mL capacity. After sedimentation, the algal abundance was evaluated using an inverted microscope (Zeiss Axiovert 135). In each chamber, small phytoplankton species were counted on the belts at $400 \times$ magnification (at least 200 individuals); larger forms (filamentous or coccal colonies) were counted on the entire bottom of the chamber at a magnification of $200 \times$. The unit length of $100 \mu \mathrm{m}$ and a surface of $300 \mu \mathrm{m}^{2}$ were considered to be one individual for filamentous and coccal colonies, respectively. Additionally, samples for taxonomic analysis of phytoplankton were collected using a plankton net $(20 \mu \mathrm{m}$ mesh size $)$ and were left without fixation to observe live specimens under a light microscope (Nikon Eclipse 80i). To determine the differences in the effects of MW and CW, the Shannon-Wiener diversity index (Shannon and Wiener, 1963) and Pielou's evenness index (Pielou, 1975) were analysed based on the abundance of the phytoplankton community.

Submerged aquatic vegetation (SAV) was compared in the growing seasons after the CW and the MW. The investigation of the macrophytes was performed in permanent study sites situated randomly in the phytolittoral zone of the lakes. The study sites were precisely marked in 2010 and located in the subsequent years (2011-2014) with a GPS receiver (Garmin $60 \mathrm{Cx})$. The samples were collected with a rake sampler from quadrats ( $0.4 \mathrm{~m}$ sides) in August of each year. Water depth of each sample was also measured. In the laboratory, plants were cleaned, dried at a temperature of $105{ }^{\circ} \mathrm{C}$ to constant weight, and weighed. A total of 300 samples were taken during the course of the study.

Non-parametric tests were used, or data were log-transformed prior to analysis if data did not meet assumptions of parametric tests. The homogeneity of variance was analysed with the Levene test and normality of data was tested with the Lillefors test. The correlations between water transparency (SD and $K_{d}$ ), phytoplankton abundance (the concentration of chlorophyll $a$ ), and SAV were evaluated with Spearman's test.

Two-way ANOVA was applied to test the influence of the type of lake (of different ecological status) on the expected effects of the CW and MW (the types of winter) on the physical and chemical parameters of water and the abundance of phytoplankton. The influence of the lake type on the reaction of the macrophytes (SAV) after the CW and MW was investigated using ANCOVA, in which sampling water depth was included as a covariate. All calculations were performed with Statistica 10 according to Sokal and Rohlf (1995).

\section{Results}

\subsection{Meteorological backgrounds}

In the West Polesie region, the mean air temperature in January through March during 2010-2014 varied from $-3{ }^{\circ} \mathrm{C}$ 
Table 2. Mean air temperature $\left({ }^{\circ} \mathrm{C}\right)$ in January-March during the cold $(\mathrm{CW})$ and mild winters $(\mathrm{MW})$ and in spring (April) and the term of ice break-up $\left(L_{\mathrm{bd}}\right)$ in 2010-2014.

\begin{tabular}{|c|c|c|c|c|c|c|c|}
\hline Year & Type of winter & January & February & March & Average for winter & April & $L_{\mathrm{bd}}$ \\
\hline 2010 & $\mathrm{CW}$ & -9 & -2.9 & 2.9 & -3 & 9.1 & Begining-of-April \\
\hline 2011 & MW & -1.6 & -4.6 & 2.9 & -1.4 & 9.8 & Begining-of-March \\
\hline 2012 & $\mathrm{CW}$ & -2.4 & -8 & 4 & -2.1 & 9.3 & End-of-March \\
\hline 2013 & $\mathrm{CW}$ & -4.2 & -0.8 & -2.4 & -2.5 & 8.1 & End-of-April \\
\hline 2014 & MW & -3.7 & 0.9 & 6 & 1.1 & 9.9 & Mid-February \\
\hline
\end{tabular}

in 2010 to $1.1^{\circ} \mathrm{C}$ in 2014 (Tab. 2). The yearly mean air temperatures during winters were below the average observed in this period $\left(-1.6^{\circ} \mathrm{C}\right)$ in 2010,2012 , and 2013 , and hence these years were designated as representatives for the cold winters (CW), whereas the air temperatures in 2011 and 2014 were above the aforementioned value and so these years were designated as mild winters (MW). The variation of thermal conditions in some months was considerably high, e.g. in January (from -9 to $-1.6{ }^{\circ} \mathrm{C}$ ) and February (from -8 to $0.9{ }^{\circ} \mathrm{C}$ ), which could influence ice phenology in these years, e.g. the ice cover break-up date. Only in April were all mean air temperatures in 2010-2014 above zero; these varied to a small extent, from $8.1{ }^{\circ} \mathrm{C}$ in 2013 to $9.9^{\circ} \mathrm{C}$ in 2014 (Tab. 2).

In the studied lakes, the last ice break-up dates $\left(L_{\mathrm{bd}}\right)$ in 2010-2014 varied in a broad range from mid-February (winter period) to the end of April (spring period, Tab. 2). After the cold winters $(\mathrm{CW})$ the $L_{\mathrm{bd}}$ was observed very late, in the beginning of April in 2010, at the end of March in 2012, and at the end of April in 2013. A particularly late $L_{\mathrm{bd}}$ was observed in 2013 due to an anomalously cold March. The very late iceout in 2013 was also associated with the lowest values of mean air temperature in April $\left(8.1^{\circ} \mathrm{C}\right)$, compared to means for that month in other years. In the MW, the $L_{\mathrm{bd}}$ occurred in the beginning of March in 2011 and in mid-February in 2014 (Tab. 2).

During the study period (2010-2014), the total precipitation in the following hydrological years varied in a broad range, from $481.5 \mathrm{~mm}$ in 2013 to $717.76 \mathrm{~mm}$ in 2011 . Nevertheless, the mean total precipitation during hydrological years with the MW was coupled with higher precipitation $(717.4 \mathrm{~mm})$, whereas the mean total precipitation in hydrological years with the CW were lower, $579.8 \mathrm{~mm}$.

The effect of wind action on the mixing regime of the studied lakes was negligible. The values of the expected depth of epilimnion $\left(E_{m}\right)$ ranged from $2.52 \mathrm{~m}$ to $3.48 \mathrm{~m}$, and was even lower than the values of the lakes mean depth (Tab. 1).

\subsection{Characteristics of physical and chemical parameters}

All changes in air temperature, the $L_{\mathrm{bd}}$, and the total precipitation had an effect on the physical, chemical and biological parameters during the vegetation season. Within the investigated parameters, the mean values of soluble and total phosphorus, dissolved inorganic nitrogen, and TN:TP ratio were similar in the two types of lakes (PDL and MDL). Other physical and chemical parameters (total nitrogen, transparency, and attenuation coefficient) and all biological parameters of the water differed in the compared types of lakes, PDL and MDL (Figs. 1 and 2, Tab. 3). The concentration of total nitrogen was slightly but significantly higher in the PDL $\left(3.09 \mathrm{mg} \mathrm{L}^{-1}\right)$ than in the MDL $\left(2.38 \mathrm{mg} \mathrm{L}^{-1}\right)$. Similarly, the parameters describing the light climate in the water, SD and $K_{d}$, were almost twofold lower and higher, respectively, in the PDL than in the MDL; SD was $1.5 \mathrm{~m}$ in PDL and $3.2 \mathrm{~m}$ in MDL and $K_{d}$ was $1.65 \mathrm{~m}^{-1}$ in PDL and $0.82 \mathrm{~m}^{-1}$ in MDL. Hence, water transparency (SD) was highly negatively correlated with the light attenuation coefficient $\left(K_{d}\right.$; Spearman's $R=-0.84, p<0.001, n=160)$. Nevertheless, in both types of lakes, only the values of $K_{d}$ were significantly affected by the MW (Fig. 1f, Tab. 3). Independent of the lake type, the concentration of soluble (DIN) and total nitrogen (TN) and TN:TP ratio were significantly higher, whereas the values of soluble $\left(\mathrm{P}-\mathrm{PO}_{4}\right)$ and total phosphorus (TP) were significantly lower after the MW compared with the corresponding values after the CW (Fig. 1, Tab. 2). Nevertheless, the effects of the interaction between the type of winter and the type of lake was insignificant for the values of the physical and chemical parameters.

\subsection{Characteristics of phytoplankton community structure}

Among the biological parameters associated with the phytoplankton community, the mean concentration of chlorophyll $a$ and the phytoplankton biomass were much higher in the PDL (29.53 $\mu \mathrm{g} \mathrm{L}^{-1}$ and $11.69 \mathrm{mg} \mathrm{L}^{-1}$, respectively) than in the MDL $\left(9.02 \mu \mathrm{gL}^{-1}\right.$ and $\left.4.23 \mathrm{mgL}^{-1}\right)$, which highly differentiated the underwater light climate, as expressed by the values of SD (Spearman's $R=-0.88$ and $-0.85, p<0.001$, $n=160$ ) and $K_{d}$ (Spearman's $R=0.83$ and $0.82, p<0.001$, $n=160$ ). The values describing the phytoplankton community (chlorophyll $a$ concentration, total phytoplankton biomass, and biomass of Cryptophyceae) were correlated with the type of winter and were significantly higher in the vegetation season after the MW than that after the CW (Tab. 3, Fig. 2a-c), but the increases in these parameters after the MW was statistically important only in the PDL. The most common species of the Cryptophyceae were Cryptomonass marssonii Skuja and Cryptomonas curvata Ehrenberg. Two other groups, Cyanobacteria and Chlorophyta, made up high proportions of the phytoplankton biomass, but the effect of winter type on their biomass was insignificant. Nevertheless, the effect of the PDL versus the MDL was strong in both groups (Tab. 3). The mean biomass of Cyanobacteria was $4.19 \mathrm{mg} \mathrm{L}^{-1}$ and $1.29 \mathrm{mg} \mathrm{L}^{-1}$ in the PDL and the MDL respectively, whereas the mean biomass 

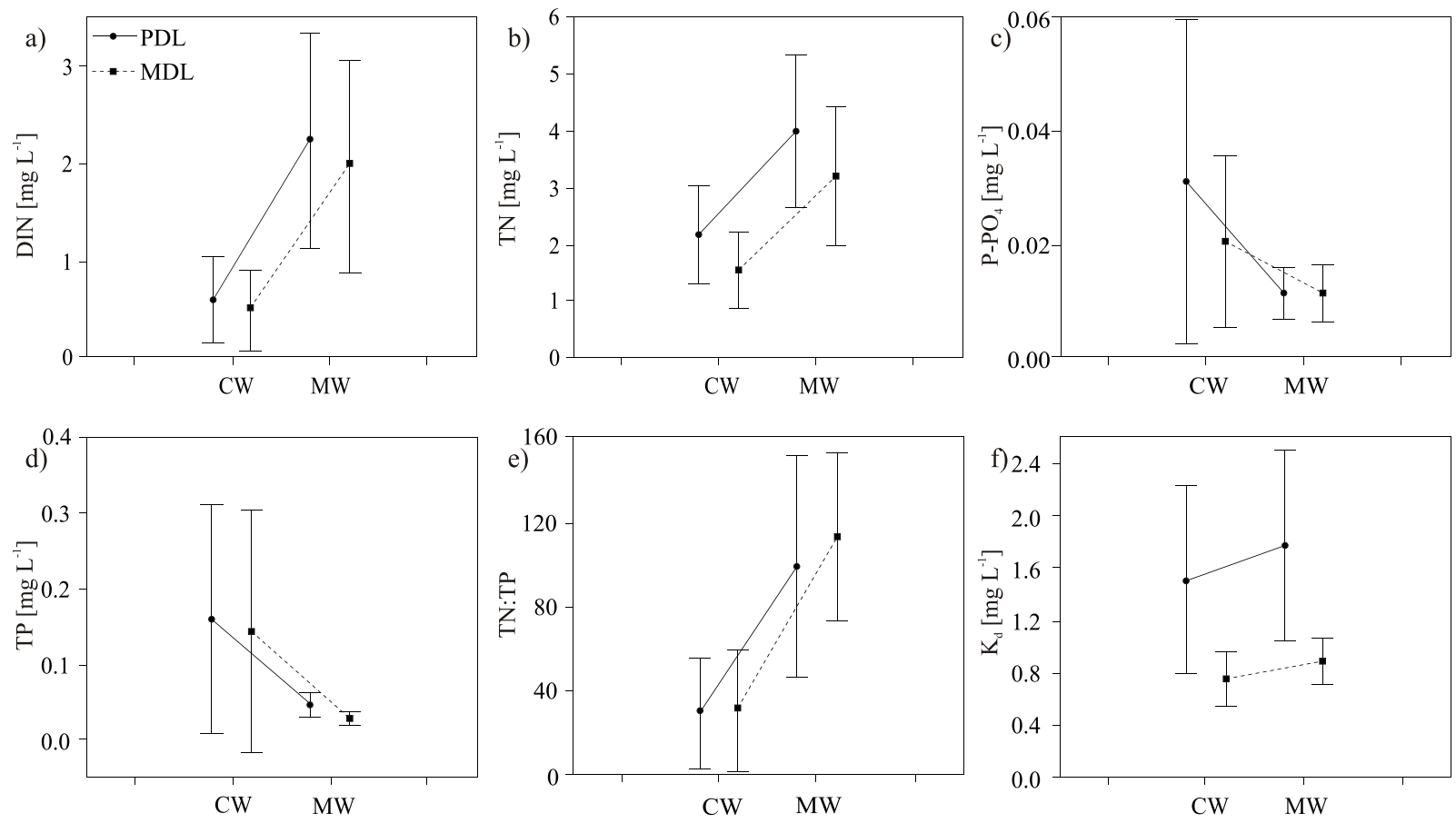

Fig. 1. Mean values ( \pm standard deviations) of selected physical and chemical parameters of water in the phytoplankton-dominated lakes (PDL) and macrophyte-dominated lakes (MDL) after cold winters (CW) and mild winters (MW). Abbreviations: TP - total phosphorus, TN - total nitrogen, $K_{d}-$ the attenuation coefficient.

of Chlorophyta was $3.89 \mathrm{mg} \mathrm{L}^{-1}$ and $1.68 \mathrm{mg} \mathrm{L}^{-1}$ respectively. Among the Cyanobacteria, the filamentous species, i.e. Limnothrix planktonica (Woloszynska) Meffert, Limnothrix redekei (Goor) Meffert, Planktothrix agardhii (Gomont) Anagnostidis et Komárek, Planktolyngbia limnetica (Lemmermann) Komárková-Legnerová \& Cronberg, or Aphanizomenon gracile (Lemmermann) Lemmermann, dominated in both types of lakes (the PDL and MDL). The Chlorophyta group was very diverse, but Coenococcus planctonicus Korshikov was the most abundant species. The proportions of other phytoplankton groups, i.e. Dinophyceae, Euglenophyta, and Bacillariophyceae, in the phytoplankton biomass were negligible. The type of winter and the type of lake had also significant effects on the phytoplankton species richness and the diversity index $\left(H^{\prime}\right)$, but there was no interaction between them (Tab. 3). Nonetheless, the species richness and the diversity index were always higher in the PDL than the MDL and after the CW than after the MW (Fig. 2d,e).

\subsection{Characteristics of macrophyte community structure}

In the studied lakes, the most common submerged aquatic macrophytes were Ceratophyllum demersum L., Myriophyllum spicatum L., and Stratiotes aloides L. In the PDL, C. demersum and $M$. spicatum were the most abundant species within the SAV. In the MDL, C. demersum predominated over S. aloides (Fig. 2f-i). Other species, e.g. Nuphar lutea (L.) Sibth. \& Sm., Elodea canadensis Michx., Potamogeton lucens L., $P$. acutifolius Link, and P. natans L. occurred only occasionally in the lakes.
The total biomass of submerged aquatic macrophytes (SAV) was correlated with underwater light climate expressed as $\operatorname{SD}(r=0.34, p<0.001, n=120)$ and, alternatively, $K_{d}(r=-$ $0.37, p<0.001, n=120)$. Moreover, the biomass of SAV was much lower in the PDL $\left(88.42 \mathrm{~g} \mathrm{~m}^{-2}\right.$ in the CW and $54.65 \mathrm{~g} \mathrm{~m}^{-2}$ in the MW), than in the MDL $\left(142.35 \mathrm{~g} \mathrm{~m}^{-2}\right.$ and $136.16 \mathrm{~g} \mathrm{~m}^{-2}$, respectively), and the differences in its total biomass between the $\mathrm{CW}$ and $\mathrm{MW}$ were also significant (Tab. 3, Fig. 2f-i). The average water depth of the occurrence of macrophytes was much higher in the MDL $(3.04 \mathrm{~m})$ than in the PDL $(2.19 \mathrm{~m})$.

The effects of the interaction between the type of winter and the type of lake was significant only in biological parameters corresponding with submerged macrophytes (Tab. 3). The biomass of SAV, M. spicatum, and S. aloides was negatively affected by poor light conditions after the MW, but this reaction was significant in the PDL only for the SAV and the biomass of $M$. spicatum and was not significant in the MDL (Fig. 2f, h). The opposite reaction was found in the biomass of $S$. aloides, in which the change was significant in the MDL and not in the PDL (Fig. 2i). Effects of the interaction and the effect of winter were not found in the biomass of $C$. demersum (Tab. 3), but its biomass was consistently higher in the MDL than the PDL (Fig. 2g). In the PDL, the biomass of SAV was the highest after the coldest winters, in 2010 and 2013 (on average from 82.04to $82.69 \mathrm{~g} \mathrm{~m}^{-2}$ ) and it was much lower after extremely mild winters, in 2011 and 2014 (from 25.84 to $52.65 \mathrm{~g} \mathrm{~m}^{-2}$ ). The biomass of SAV in the MDL was more stable, and it was from 154.48 to $162.15 \mathrm{~g} \mathrm{~m}^{-2}$ in 2010 and 2012-2014, and slightly decreased in 2011 to $141.64 \mathrm{~g} \mathrm{~m}^{-2}$. Hence, the biomass of SAV in the MDL was 

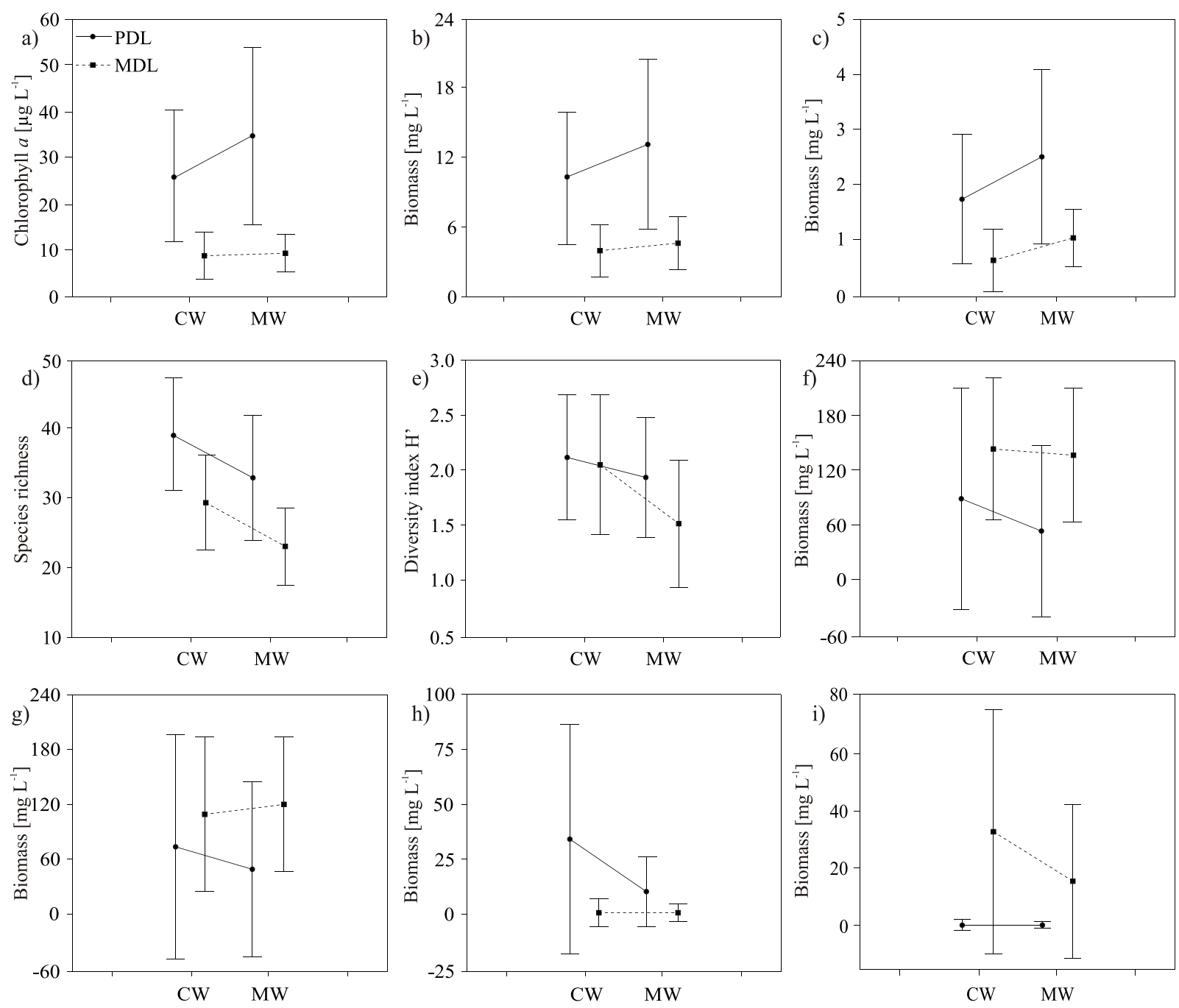

Fig. 2. Mean values ( \pm standard deviations) of selected biological parameters of water in the phytoplankton- (PDL) and macrophyte-dominated lakes (MDL) after cold winters (CW) and mild winters (MW): (a) concentration of chlorophyll $a$; (b) total biomass of phytoplankton; (c) biomass of Cryptophyceae; (d) phytoplankton species richness; (e) phytoplankton diversity index; (f) biomass of submerged aquatic vegetation; (g) biomass of Ceratophyllum demersum; (h) biomass of Myriophyllum spicatum; (i) biomass of Stratiotes aloides.

continuously very high during the study (2010-2014) despite the mean water transparency (SD) in May-July (before the time of macrophyte sampling) varying from $2.87 \mathrm{~m}$ in 2010 to $3.98 \mathrm{~m}$ in 2012, the $K_{d}$ varying from 0.69 (2012) to 0.95 (2011), and the concentration of chlorophyll $a$ and the phytoplankton biomass varying from $5.95 \mu \mathrm{g} \mathrm{L}^{-1}$ and $2.63 \mathrm{mg} \mathrm{L}^{-1}$, respectively, in 2012 to $8.37 \mu \mathrm{g} \mathrm{L}^{-1}$ and $3.94 \mathrm{mg} \mathrm{L}^{-1}$ in 2011 .

\section{Discussion}

Mild winters in the temperate regions of Central Europe, including eastern Poland, have been more prevalent as of late, and are generally caused by the process of global climate warming (Dokulil et al., 2010). The present study focused on the role of specific winter periods (CW and MW) in shaping the biomass structure of primary producers in water during the vegetation season in two groups of lakes divided on the basis of the alternative stable states proposed by Scheffer et al. (1993). The Łęczna-Włodawa Plain is characterised by the vast majority of lakes with phytoplankton domination. Only a few lakes are typical macrophyte ones. In the group of lakes we studied there is only one macrophyte dominated. We wanted to discuss the differences between the lakes that are affected by the same climatic conditions and of similar characteristics, i.e., the catchment character or human impact. In our study, the presence of the CW or the MW corresponded with the total precipitation, which also changed between years. During the study, some extreme precipitation events occurred, generally in the hydrological years in which there was the MW. Hence, higher precipitation was noted during hydrological years with an MW, whereas lower precipitation was observed in years with the $\mathrm{CW}$. This finding is in agreement with predictions of future climate warming in Central Europe, in which projected increases in winter precipitation are coupled with mild winters (MW), and at the same time decreases in precipitation 
Table 3. The effects of type of winter (CW vs. MW), type of lake (PDL vs. MDL), and the effect of the interaction between them on physical, chemical and biological parameters in the studied lakes ( $F$-test, GML model). Abbreviations: $\mathrm{CW}$ - cold winter, MW - mild winter, PDL - phytoplankton dominated lakes, MDL macrophyte dominated lakes, Chl- $a-$ the concentration of chlorophyll $a$, TB total phytoplankton biomass, H' - phytoplankton Shannon-Wiener diversity index, J - Pielou's evenness index, SAV - submerged aquatic vegetation.

\begin{tabular}{lccc}
\hline Parameter & $\begin{array}{c}\text { Type of } \\
\text { winter }\end{array}$ & $\begin{array}{c}\text { Type of } \\
\text { lake }\end{array}$ & $\begin{array}{c}\text { Type of winter } \times \\
\text { Type of lake }\end{array}$ \\
\hline DIN & $115.51^{* * *}$ & 1.78 & 0.04 \\
$\mathrm{TN}$ & $67.21^{* * *}$ & $11.05^{* *}$ & 0.12 \\
${\mathrm{P}-\mathrm{PO}_{4}}_{\mathrm{TP}}$ & $13.07^{* * *}$ & 1.77 & 1.69 \\
$\mathrm{TN}: \mathrm{TP}$ & $27.86^{* * *}$ & 0.83 & 0.01 \\
$\mathrm{SD}$ & $92.92^{* * *}$ & 0.26 & 0.88 \\
$K_{d}$ & 1.27 & $188.43^{* * *}$ & 0.82 \\
Chl-a & $4.77^{*}$ & $70.01^{* * *}$ & 0.11 \\
$\mathrm{~TB}$ & $4.31^{*}$ & $125.87^{* * *}$ & 0.99 \\
Cyanobacteria & $4.13^{*}$ & $95.71^{* * *}$ & 0.45 \\
Cryptophyceae & 0.43 & $20.06^{* * *}$ & 0.01 \\
Chlorophyta & $9.11^{* *}$ & $35.35^{* * *}$ & 0.01 \\
Species richness & 0.96 & $34.28^{* * *}$ & 0.57 \\
$\mathrm{H}$ & $20.61^{* * *}$ & $43.07^{* * *}$ & 0.4 \\
J & $9.52^{* *}$ & $5.34^{*}$ & 2.61 \\
SAV & $6.15^{*}$ & 0.98 & 2.70 \\
Ceratophyllum demersum & 0.17 & $143.71^{* * *}$ & $4.42^{*}$ \\
Myriophyllum spicatum & $18.89^{* * *}$ & $235.33^{* * *}$ & $16.41^{* * *}$ \\
Stratiotes aloides & $21.87^{* * *}$ & $497.61^{* * *}$ & $20.98^{* * *}$ \\
\hline
\end{tabular}

${ }^{*} p<0.05 ;{ }^{* *} p<0.01 ;{ }^{* * *} p<0.001$.

are coupled with hot summers (Samuelsson, 2010). Moreover, frequent presence of the MW (with higher air temperatures) can affect changes in precipitation from snow to rain, which can increase the runoff from the catchment basin, especially in winter and early spring. In consequence, the MW may disturb the equilibrium of primary producers in lakes during vegetation season through changes in the light conditions, the temperature regime, and the balance of nutrient concentrations. All of these disturbances, induced by climate change, can accelerate the natural eutrophication of lakes (Samuelsson, 2010; Dokulil et al., 2010; Dokulil, 2016).

In our study, the hydrological years with mild winter (MW) and higher precipitation affected changes in physical and chemical parameters of water. In consequence, independent of the lake type (PDL or MDL), significantly higher values of soluble and total nitrogen and TN:TP ratio and significantly lower values of soluble and total phosphorus were noted in the vegetation season after the MW. Similarly, a lack of differences in the dynamics of nutrients in water was noted in other studies on lakes with turbid- or clear-water states (Zingel et al., 2006). High nitrogen content in water after the MW may be caused by permanent water column mixing that can facilitate the release of nitrogen from the bottom sediments (Nõges et al., 1998). Conversely, high phosphorus content in water after the $\mathrm{CW}$ can be linked with intensive runoff from the catchment basin caused by snow and ice melting
(Klimaszyk and Rzymski, 2011) or as an inner source released from the deoxygenated bottom sediments during spring mixing after a winter with a long-lasting ice cover (Blank et al., 2009). Hence, the changes in the TN:TP ratio suggest a limitation role of nitrogen after the $\mathrm{CW}$ or phosphorus after the MW for the growth of primary producers in lakes. However, the phytoplankton community is more sensitive and is able to respond faster to such changes in aquatic ecosystems. Therefore, the fast-developing phytoplankton community may affect the light climate in the water column, which in turn can restrict the biomass of submerged macrophytes (SAV), especially at the beginning of the vegetation season when the SAV just starts its growth. In our study, the concentration of chlorophyll $a$, phytoplankton biomass, and biomass of the Cryptophyceae, Cyanobacteria, and Chlorophyta groups were highly affected by the type of lake and were always significantly higher in the PDL than in the MDL. However, the values of chlorophyll $a$, phytoplankton biomass, and the Cryptophyceae group were significantly higher after the MW only in the PDL, and not in the MDL. The changes in biomass of Cyanobacteria and Chlorophyta between the CW and MW were negligible, but their biomass was constantly very high during the study, especially in the PDL. Nevertheless, all of the values describing the phytoplankton community were positively correlated with the values of the attenuation coefficient $\left(K_{d}\right)$ in the PDL and the MDL, which suggested a significant role of the phytoplankton community and negligible role of water column mixing, in regulating the light climate in both types of lakes. However, the values of $K_{d}$ and water transparency (SD) were always much higher and lower, respectively, in the PDL than in the MDL. Inconsiderable effect of wind action on the process of water mixing in the studied lakes was confirmed by the values of expected depth of epilimnion $\left(E_{m}\right)$ calculated on the basis of Patalas (1984) formula (Tab. 1). Nevertheless, such values of $E_{m}$ comparing to maximum depth of the lakes, which ranged from $7.1 \mathrm{~m}$ to $10.3 \mathrm{~m}$ can support the sediment resuspension process during mild winters or in spring, when the strong thermal stratification does not yet exist, and affect physical, chemical and biological parameters in water.

The aforementioned changes in the studied lakes affected the biomass of submerged macrophytes (SAV), but the response of this group of primary producers to the MW was significant only in the PDL and not in the MDL, in which the mean biomass of SAV was maintained almost at the same level after both types of winter. The lack of differences in the biomass of both primary producers (macrophytes and phytoplankton) in the vegetation season after both $\mathrm{CW}$ and MW in the MDL suggests that macrophyte-dominated lakes can be more resistant to climate warming than the PDL. The reason is clear enough: macrophytes can outcompete the phytoplankton community in the MDL by taking or release the nutrients, i.e. nitrate, phosphate, or dissolved inorganic carbon, not only from the water but also from the bottom sediments, and can protect the bottom sediments against resuspension processes (van Donk and van de Bund, 2002; Li et al., 2008; Lu et al., 2018). However, in our study the concentration of dissolved inorganic nitrogen (DIN) strongly increased after the MW, and thus the phytoplankton species should have had favourable conditions for their growth, but they did not 
develop well. This could be connected to the low content of soluble phosphorus in the water, which can limit phytoplankton growth. However, this phenomenon may have a different explanation. It may be the allelopathic effect of macrophytes on phytoplankton, which was not verified in our work. Nevertheless, there is a lot of work describing some inhibitory effects of particular macrophyte species on the phytoplankton community (Mulderij et al., 2005, 2007; Sugier et al., 2010; Kosten et al., 2011; Pełechata et al., 2015; Mohamed, 2017). The two submerged macrophyte species that dominated in the MDL, Ceratophyllum demersum and Stratiotes aloides, are well-known as producers of allelopathic substances that are able to inhibit phytoplankton growth, e.g. Cyanobacteria or Chlorophyta (Mulderij et al., 2005, 2007; Hu and Hong, 2008; Sugier et al., 2010; Mohamed, 2017), which were frequent in the phytoplankton biomass in the MDL. However, the mean biomass of $S$. aloides was notably lower after the MW than after the $\mathrm{CW}$, whereas $C$. demersum maintained almost the same biomass after both types of winter. The reason for this may be that $C$. demersum has a high tolerance to shade (Ali et al., 1995, 2011; Ejankowski and Solis, 2015), which was very likely because the values of the light attenuation coefficient $\left(K_{d}\right)$ also significantly increased in the MDL after the MW. Hence, the role of the MW in decreasing of $S$. aloides biomass in the MDL may be an additional factor supporting the hypothesis of a continuous decline of the biomass of S. aloides, as an effect of habitat destruction or changes in water quality, in European lakes (Smolders et al., 2003; Sugier et al., 2010; Aedo et al., 2015). Nevertheless, extensive submerged vegetation in the MDL maintained almost equal biomass independent of the type of winter, which could have a generally positive impact on the biomass of zooplankton species, e.g. herbivorous ciliates, hampering phytoplankton development in such types of lakes (Schriver et al., 1995; Jeppesen et al., 1998; Zingel et al., 2006).

Conversely, the mean biomass of phytoplankton and concentration of chlorophyll $a$ were constantly very high and were at least two times higher in the PDL than in the MDL. Furthermore, their values significantly increased in the PDL after the MW, which coupled with simultaneous decreases of the SAV. In the PDL, the dominant species representing SAV were $C$. demersum and Myriophyllum spicatum. However, as with the biomass of $S$. aloides in the MDL, the biomass of $M$. spicatum decreased in the PDL after the MW, whereas the biomass of $C$. demersum only slightly (but not significantly) decreased after the MW. The presence of $C$. demersum in both types of lakes, regardless of their differences, is evidence of their high tolerance to different trophic states. Moreover, in some circumstances, e.g. domination of cyanobacteria in turbid, eutrophic waters (the PDL), C. demersum can produce compounds that enable an enhanced defence reaction against other competitors (Kurashov et al., 2018). The phytoplankton community in the PDL was dominated by several species belonging to the genera Limnothrix, Planktothrix, Planktolyngbya, Aphanizomenon, Cryptomonas, and Coenococcus. In consequence, the phytoplankton species outcompeted the SAV. This was not due to the low concentration of nutrients, which were generally at sufficient levels for the development of both primary producers, but with the low availability of light in water (very high light attenuation coefficient values), restricted by the increasing biomass of phytoplankton after the MW.
Hence, decreasing biomass of $M$. spicatum, which is characterised as a light-demanding species with low tolerance to water turbidity (Haslam, 1997; Tóth and Haradek, 2011) and almost no changes in the biomass of shade-tolerant C. demersum, seems to be justified. Nevertheless, high biomass of phytoplankton, with the dominance of Cyanobacteria which are able to excrete allelopathic substances, can also be responsible for limitation of the biomass of SAV. For example, microcystins or anatoxins-a produced by filamentous cyanobacteria, i.e. Planktothrix or Aphanizomenon, which dominated in the PDL, are able to inhibit the growth of $C$. demersum (Pflugmacher, 2004; Szigeti et al., 2010) or M. spicatum (Rojo et al., 2013).

Interesting also is the fact that after the MW, the phytoplankton species richness, as well as the phytoplankton diversity, notably decreased in both types of lakes (PDL and MDL). Moreover, a withdrawal effect of certain submerged macrophyte species sensitive to light deficiency after the MW, e.g. M. spicatum in the PDL or S. aloides in the MDL, may be evidence of the loss of macrophyte diversity. This suggests that the presence of the mild winters, as an effect of global warming, can affect phytoplankton and macrophyte composition during the vegetation season regardless of the type of lake, which should be taken into account in future studies involving the two alternative stable states of shallow lakes.

Our results showed that changes in water quality after mild winters had a decreasing effect not only on the total biomass of vegetation, but also on the structure of the macrophyte community, i.e. relative abundance of particular macrophyte species in the total biomass of SAV. Moreover, this effect was also extended to the phytoplankton biomass, which in the macrophyte-dominated lakes seems to play a small role, whereas in the phytoplankton-dominated lakes, its role is significant and the phytoplankton community is generally responsible for shaping the biomass of primary producers. Furthermore, the structure of the macrophytes and phytoplankton in lakes after mild winters can change due to various responses/sensitivities of particular species to the alterations of water quality or competition between primary producers expressed, e.g. as decreasing biomass of light-demanding species and growth of shade-tolerant species.

\section{Conclusion}

- Mild winters can affect physical and chemical parameters of water, as well as the biomass of primary producers in eutrophic lakes in the temperate zone.

- Mild winters caused low species richness and phytoplankton diversity in both types of lake, but the MW affected the amount of phytoplankton only in the PDL.

- The effect of mild winters on the SAV was related to poor light climate in water. A decrease in macrophyte biomass was correlated with a simultaneous increase in the light attenuation coefficient caused by high phytoplankton biomass, especially in the PDL.

- Retreat of two light-demanding macrophyte species, e.g. $M$. spicatum in the PDL and S. aloides in the MDL, as well as the lack of reaction by shade-tolerant species $C$. demersum, after the mild winters showed the role of 
climate warming in shaping macrophyte composition in water.

- Poor underwater light climate after the MW was stressful for the SAV in the phytoplankton-dominated lakes, whereas it was not in the macrophyte-dominated ones.

\section{References}

Aedo C, Medina L, Barberá, P, Fernández-Albert M. 2015. Extinctions of vascular plants in Spain. Nord J Bot 33: 83-100.

Ali MM, Hamad AM, Springuel IV, Murphy KJ. 1995. Environmental factors affecting submerged macrophyte communities in regulated water bodies in Egypt. Arch Hydrobiol 133: 107-128.

Blank K, Haberman J, Haldna M, Laugaste R. 2009. Effect of winter conditions on spring nutrient concentrations and plankton in a large shallow Lake Peipsi (Estonia/Russia). Aquat Ecol 43: 745-753.

Degirmendžić J, Kożuchowski K, Zmudzka E. 2004. Changes of air temperature and precipitation in Poland in the period 1951-2000 and their relationship in to atmospheric circulation. Int J Climatol 24: $291-310$.

Dokulil MT, Teubner K, Jagsch A, et al. 2010. The impact of climate change on lakes in Central Europe. In: George G, ed. The Impact of Climate Change on European Lakes. Dordrecht: Springer, pp. $387-410$

Dokulil MT. 2016. Climate impacts on ecohydrological processes in aquatic systems. Ecohydrol Hydrobiol 16: 66-70.

Ejankowski W, Lenard T. 2014. Trophic state of a shallow lake with reduced inflow of surface water. Arch Environ Prot 40: 3-11.

Ejankowski W, Lenard T. 2015. Climate driven changes in the submerged macrophyte and phytoplankton community in a hard water lake. Limnologica 52: 59-66.

Ejankowski W, Solis M. 2015. Response of hornwort (Ceratophyllum demersum L.) to water level drawdown in a turbid water reservoir. Appl Ecol Environ Res 13: 219-228.

Furtak T, Sobolewski W, Turczyński M. 1998. Charakterystyka zlewni jezior. In: Harasimiuk M, Michalczyk Z, Turczyński M, Eds. Jeziora łęczyńsko-włodawskie. Monografia przyrodnicza. Biblioteka Monitoringu Środowiska, Wydawnictwo UMCS, Lublin, pp. 73-91.

Haslam SM. 1997. The river scene: ecology and cultural heritage. Cambridge: Cambridge University Press, 344 p.

Hermanowicz W, Dojlido J, Dożańska W, Koziorowski B, Zerbe J. 1999. Fizyczno-chemiczne badanie wody i ścieków. Warszawa: Wyd. Arkady, 556 p.

Hillebrand H, Dürselen CD, Kirschtel D, Pollingher U, Zohary T. 1999. Biovolume calculation for pelagic and benthic microalgae. J Phycol 35: 403-424.

Hu H, Hong Y. 2008. Algal-bloom control by allelopathy of aquatic macrophytes-A review. Front Environ Sci Eng China 2: 421-438.

Jeppesen E, Lauridsen TL, Kairesalo T, Perrow MR. 1998. Impact of submerged macrophytes on fish-zooplankton interactions in lakes. In Jeppesen E, Søndergaard M, Søndergaard M, Christoffersen K, eds. The structuring role of submerged macrophytes in lakes. New York: Springer, pp. 91-114.

Jones I, Sahlberg J, Persson I. 2010. Modelling the impact of climate change on the thermal characteristics of lakes. In: George G, ed. The Impact of Climate Change on European Lakes. Dordrecht: Springer, pp. 103-120.

Kaszewski BM, Siwek K, Gluza AF, Siłuch M. 2009. Changes of the selected climatic components in the "West Polesie" Biosphere Reserve during 1951-2006 period. In Chmielewski T, J, Słotwiński
C, eds. Nature and Landscape monitoring system in the West Polesie region. Warszawa: Wyd. PZN, pp. 138-152.

Kirk JTO. 1994. Light and photosynthesis in aquatic ecosystems. Cambridge: Cambridge Univ. Press, 509 p.

Klimaszyk P, Rzymski P. 2011. Surface runoff as a factor determining trophic state of midforest lake. Pol J Environ Stud 20: 1203-1210.

Kondracki J. 2002. Geografia regionalna Polski. Warszawa: Wyd. Nauk. PWN, 440 p.

Kosten S, Jeppesen E, Huszar VLM, et al. 2011. Ambiguous climate impacts on competition between submerged macrophytes and phytoplankton in shallow lakes. Freshw Biol 56: 1540-1553.

Kurashov EA, Mitrukova GG, Krylova JV. 2018. Interannual variability of low-molecular metabolite composition in Ceratophyllum demersum (Ceratophyllaceae) from a floodplain lake with a changeable trophic status. Contemp Probl Ecol 11: 179-194.

Laugaste R, Haberman J, Blank K. 2010. Cool winters versus mild winters: effects on spring plankton in Lake Peipsi. Est J Ecol 59: $163-183$.

Lenard T, Ejankowski W. 2017. Natural water brownification as a shift in the phytoplankton community in a deep hard water lake. Hydrobiologia 787: 153-166.

Lenard T, Wojciechowska W. 2013. Phytoplankton diversity and biomass during winter with and without ice cover in the context of climate change. Pol J Ecol 61: 739-748.

Li E, Li W, Liu G, Yuan L. 2008. The effect of different submerged macrophyte species and biomass on sediment resuspension in a shallow freshwater lake. Aquat Bot 88: 121-126.

Lu J, Bunn SE, Burford MA. 2018. Nutrient release and uptake by littoral macrophytes during water level fluctuations. Sci Total Environ 622-623: 29-40.

Magnuson JJ, Robertson DM, Benson BJ, et al. 2000. Historical trends in lake and river ice cover in the northern hemisphere. Science 289: 1743-1746.

Marszelewski W, Skowron R. 2006. Ice cover as an indicator of winter air temperature changes: Case study of the Polish Lowland lakes. Hydrolog Sci J 51: 336-349.

Mohamed ZA. 2017. Macrophytes-cyanobacteria allelopathic interactions and their implications for water resources management - A review. Limnologica 63: 122-132.

Mulderij G, Mooij WM, Smolders AJP, Van Donk E. 2005. Allelopathic inhibition of phytoplankton by exudates from Stratiotes aloides. Aquat Bot 82: 284-296.

Mulderij G, Mau B, van Donk E, Gross EM. 2007. Allelopathic activity of Stratiotes aloides on phytoplankton - towards identification of allelopathic substances. Hydrobiologia 584: 89-100.

Nõges P, Järvet A, Tuvikene L, Nõges T. 1998. The budgets of nitrogen and phosphorus in shallow eutrophic Lake Võrtsjärv. Hydrobiologia 363: 219-227.

Nush EA. 1980. Comparison of different methods for chlorophyll and pheopigment determination. Arch Hydrobiol - Beiheft Ergebnisse der Limnologie 14: 14-36.

Patalas K. 1984. Mid-summer mixing depths of lakes of different latitudes. Int Ver Theor Angew Limnol Verh Verh 22: 97-102.

Pełechata A, Pełechaty M, Pukacz A. 2015. Winter temperature and shifts in phytoplankton assemblages in a small Chara-lake. Aquat Bot 124: 10-18.

Pflugmacher S. 2004. Promotion of oxidative stress in the aquatic macrophyte Ceratophyllum demersum during biotransformation of the cyanobacterial toxin microcystin-LR. Aquat Toxicol 70: $169-178$. 
Peng S, Piao S, Ciais Ph, Friedlingstein P, Zhou L, Wang T. 2013. Change in snow phenology and its potential feedback to temperature in the Northern Hemisphere over the last three decades. Environ Res Lett 8: 014008.

Pielou EC. 1975. Ecological diversity. New York: John Wiley \& Sons. Rojo C, Segura M, Cortes F, Rodrigo MA. 2013. Allelopathic effects of microcystin-LR on the germination, growth and metabolism of five charophyte species and a submerged angiosperm. Aquat Toxicol 144-145: 1-10.

Samuelsson P. 2010. Using regional climate models to quantify the impact of climate change on lakes. In: George G, ed. The Impact of Climate Change on European Lakes. Dordrecht: Springer, pp. 15-32.

Shannon CE, Wiener W. 1963. The mathematical theory of communication. Urbana, IL: University of Illinois Press.

Scheffer M, Hosper SH, Meijer M-L., Moss B, Jeppesen E. 1993. Alternative equilibria in shallow lakes. Trends Ecol Evol 8: 275-279.

Scheffer M, Van Nes EH. 2007. Shallow lakes theory revisited: various alternative regimes driven by climate, nutrients, depth and lake size. Hydrobiologia 584: 455-466.

Schriver P, Bøgestrand J, Jeppesen E, Søndergaard M. 1995. Impact of submerged macrophytes on fish-zooplanktonphytoplankton interactions: large-scale enclosure experiments in a shallow eutrophic lake. Freshw Biol 33: 255-270.

Smolders AJP, Lamers LPM, Den Hartog C, Roelofs JGM. 2003. Mechanisms involved in the decline of Stratiotes aloides L. in the Netherlands: sulphate as a key variable. Hydrobiologia 506: 603-610.

Sokal RR, Rohlf FJ. 1995. Biometry. New York: W.H. Freeman and Company, $887 \mathrm{p}$.
Sugier P, Lorens B, Chmiel S, Turczyński M. 2010. The influence of Ceratophyllum demersum L. and Stratiotes aloides L. on richness and diversity of aquatic vegetation in the lakes of mid-eastern Poland. Hydrobiologia 656: 43-53.

Szigeti ZM, Jambrik K, Roszik J, et al. 2010. Cytoskeletal and developmental alterations in Ceratophyllum demersum induced by microcystin-LR - a cyanobacterial toxin. Aquat Bot 92: 179-184.

Todd MC, Mackay AW. 2003. Large-scale climatic controls on Lake Baikal ice cover. J Clim 16: 3186-3199.

Tóth VR, Haradek S. 2011. Seasonal shift of dominance in a submerged rooted macrophyte community of Lake Balaton. Ann Limnol 47: 141-150.

Utermöhl H. 1958. Zur Vervolkommnung der quantitativen Planktonmethodik. Mitt Int Ver für Theor Angew Limnol 9: 1-38. van Donk E, van de Bund W. 2002. Impact of submerged macrophytes including charophytes on phyto- and zooplankton communities: allelopathy versus other mechanisms. Aquat Bot 72: 261-274.

Weyhenmeyer GA, Meilei M, Livingstone DM. 2004. Nonlinear temperature response of lake ice breakup. Geophys Res Lett 31: L07203.

Weyhenmeyer GA, Meilei M, Livingstone DM. 2005. Systematic differences in the trend towards earlier ice-out on Swedish lakes along a latitudinal temperature gradient. Verh Intern Verein Limnol 29: $257-260$.

Weyhenmeyer GA, Westöö AK, Willén E. 2008. Increasingly ice-free winters and their effects on water quality in Sweden's largest lakes. Hydrobiologia 599: 111-118.

Wilgat T, Michalczyk Z, Turczyński M, Wojciechowski K. 1991. The Łęczna-Włodawa Lakes. Studia Ośr Dok Fizjogr PAN 19: 23-140.

Zingel P, Nõges P, Tuvikene L, et al. 2006. Ecological processes in macrophyte- and phytoplankton-dominated shallow lakes. Proc Estonian Acad Sci Biol Ecol 55: 280-307.

Cite this article as: Lenard T, Ejankowski W, Poniewozik M. 2019. Different responses of primary producers to mild winter in macrophyteand phytoplankton-dominated lakes. Knowl. Manag. Aquat. Ecosyst., 420, 44. 